\title{
Web accessibility and technology protection measures: Harmonizing the rights of persons with cognitive disabilities and copyright protections on the web
}

\author{
G. Anthony Giannoumi ${ }^{1}$, Molly Land ${ }^{2}$, Wondwossen M. Beyene ${ }^{1}$, \& Peter Blanck ${ }^{3}$ \\ ${ }^{1}$ Oslo and Akershus University College of Applied Sciences, Oslo, Norway \\ ${ }^{2}$ University of Connecticut School of Law, Hartford, CT, United States \\ ${ }^{3}$ Burton Blatt Institute at Syracuse University, Syracuse, NY, United States
}

\begin{abstract}
The United Nations Convention on the Rights of Persons with Disabilities (CRPD) obligates State Parties to ensure full and equal access to the web for persons with disabilities. However, copyright law and policy sometimes poses challenges to realizing full and equal access to the web for persons with varying physical, mental, and cognitive disabilities. Recent developments in international law and policy that promote the use of technological protection measures (TPM) as a means for protecting copyrighted digital content on the web create barriers to accessibility for certain individuals with disabilities. This article uses theories of multilevel governance and social regulation to explore the relationship among laws and policies that aim to ensure web accessibility, and laws and policies to preserve and promote the use of TPM. It employs a case study of U.S. law and policy to examine how different levels of governance have ensured and supported the rights of persons with cognitive disabilities and web content publishers. This article argues that the Marrakesh Treaty acts as a bridge between the copyright and human rights regimes, can promote the meaningful participation of persons with an array of cognitive and other disabilities in the design and implementation of national and international copyright laws and policies, and thus fosters harmonization of TPM with the principles of web accessibility.
\end{abstract}

Keywords: technology protection measures; web accessibility; disability rights; copyright; Marrakesh Treaty

\section{Introduction}

The 2008 United Nations Convention on the Rights of Persons with Disabilities (CRPD) obligates State Parties to ensure, among other things, full and equal access to the web for persons with disabilities (United Nations, 2006). Consistent with conceptualizations of disability used in the CRPD and in disability studies research, this article refers to disability as a dynamic concept that results from the interaction between an individual and the social and attitudinal environment that may limit and prevent their full and equal participation in society (Bickenbach, Chatterji, Badley, \& Ustün, 1999; Hughes, 2007; Blanck \& Flynn, 2017). Some scholars and advocates reject the use of the term persons with disabilities in favor of disabled people and disability-specific terms such as blind or partially sighted, deaf or hard of hearing or autistic (EFHOH, 2017; Kenny et al., 2016; NAD, 2017; Oliver \& Barnes, 2012; Sinclair, 2013; Vaughan, 1997; WBU, 2017; WFD, 2017). Nonetheless, we use the term persons with disabilities because it is consistent with the "person-first" approach used in the CRPD (Blaska, 1993; United Nations, 2006). 
While research on web accessibility often has focused on the experiences of persons with sensory and physical disabilities, this article examines the particular relationship between persons with cognitive disabilities and the barriers that they experience using the web (Tatomir \& Durrance, 2010; Yi, 2015; Green \& Huprich, 2009; Lazar et al., 2010; De Andrés, Lorca, \& Martínez, 2010). Persons with cognitive disabilities (e.g., developmental and intellectual disabilities, traumatic brain injury, dyslexia and autism) refer to persons who experience barriers using web content that is not designed to take into account limitations in memory, problem-solving, attention, and comprehension (Blanck, 2014a, 2016a). This article recognizes that conceptualizations of persons with cognitive disabilities may vary due to social, cultural or political norms. This article argues that persons with cognitive disabilities may include persons with intellectual, developmental or print disabilities and persons with multiple disabilities may have cognitive as well as other sensory or physical impairments.

Web and web content developers may ensure equal access to web content (e.g., text, images, sounds, videos and animations) for persons with a range of physical, sensory, cognitive and mental health disabilities by providing adaptive and personalized systems that make content simpler and easier to use. For example, personalizing symbols, such as icons, can simplify navigation on a website and provide an easier to read version of a website, which improves access to its content (Blanck, 2014a; Vanderheiden et al., 2012; W3C, 2016). Content could also be presented in alternative formats to give users the freedom to choose whichever format is most usable and accessible for them. Research suggests that creating accessible web content for persons with cognitive disabilities often promotes web accessibility for persons with disabilities more broadly by, among other things, ensuring compatibility with assistive technologies, such as screen readers (Beyene, 2016; Blanck, 2014a; Dawe, 2006; Friedman \& Bryen, 2007). Assistive technologies can also enhance an individual's ability to access web content by changing the mode of interaction (e.g., from visual to visual and aural). Legal scholars characterize the accommodations that ensure web accessibility as part of a "right to the web" or "eQuality" for persons with cognitive disabilities (Blanck, 2014a).

This article recognizes that the diversity among persons with cognitive disabilities may mean that websites cannot be designed accessibly - e.g., persons with cognitive disabilities may include persons who have experienced traumatic brain injury and have been medically diagnosed as unresponsive (Laureys et al., 2010). In addition, practitioners have struggled to develop standards for web accessibility that are also fully accessible for persons with cognitive disabilities (Friedman \& Bryen, 2007; Kreps \& Goff, 2015; Small, Schallau, Brown, \& Appleyard, 2005).

Governments, researchers, legal scholars and advocates are divided on whether, how, and to what extent, the economic and ownership rights (e.g., copyright of digital intellectual property) of web content may be appropriately balanced with the full and equal right to the web for persons with disabilities. Web content publishers typically maintain copyright ownership over their published works, which prohibits the unauthorized reproduction and alteration of that work. Web content publishers may use technological protection measures (TPM) to restrict access to web content in an attempt to prevent and deter copyright infringement. However, in some circumstances, TPM may constitute a barrier to web access for persons with cognitive disabilities. For example, a web content publisher may use TPM to prevent an individual from changing content to an "easy-toread" or plain format text. TPM also may prevent assistive technologies from effectively rendering content in accessible formats and changing the primary mode of interaction. Laws that enforce TPMs may treat circumvention of these technologies as a violation subject to civil or criminal penalties (Blanck, 2014a; Ellis \& Kent, 2011). While this article recognizes the relevance of technical solutions for removing barriers to participation for persons with disabilities, it is beyond the scope of this article to comprehensively examine how and to what extent TPM create barriers to web accessibility for persons with cognitive disabilities.

Recent developments in international law and policy promote the use of TPM as a means for protecting copyrighted content on the web. However, research has yet to explore the relationship between laws and policies that aim to ensure web accessibility, and laws and policies to promote the use of TPM. This article explores the tensions between web accessibility for persons with cognitive disabilities and the use of TPM. We ask, "How have different levels of governance ensured and supported the rights of persons with cognitive disabilities and web content publishers?" 
This article proceeds in five sections. First, it frames the analysis of web accessibility and TPM using theories of multilevel governance and social regulation. Second, it outlines the methods of analysis. Third, this article analyses the literature on web accessibility and copyright law and policy as it pertains to a "right to the web" for persons with cognitive disabilities. Fourth, it examines law and policy documents that aim to promote web accessibility and the use of TPM for copyright holders. Fifth, it concludes by discussing our findings in relation to theories of multilevel governance and social regulation, posing recommendations for future research and practice.

\section{Analytic Framework}

Theories of multilevel governance have emerged, in part, from research on policy implementation - i.e., the examination of how rules affect behavior (Hill \& Hupe, 2008). According to leading scholars in the field, the relationship between law on the books and law in action is mediated by a variety of complex mechanisms that influence and are influenced by the behavior of policy actors on a local, national and international scale (Hill \& Hupe, 2008; Levi-Faur, 2011). Essentially, theories of multilevel governance seek to answer "who acts where, doing what, on which scale and how?" (Hill \& Hupe, 2008). Theories and models of policy implementation and social regulation provide a useful analytic lens for examining the relationship between web accessibility and TPM law and policy. This article refers to policy implementation as the events that occur between policy expectations and policy results (Hill \& Hupe, 2008). These events are related to the design of social regulations, which this article refers to as policy actors' use of different policy instruments to persuade and force market actors to achieve social outcomes (Levi-Faur, 2011). Theories and models of implementation and social regulation provide a useful perspective for analyzing the role of laws and policies that promote TPM as one important mediating factor in the realization of web accessibility for persons with cognitive disabilities.

\section{Policy Implementation}

Examining policy implementation in the context of TPM and accessibility provides an opportunity to investigate the processes involved in realizing policy outcomes in relation to stated objectives. Hill and Hupe (2008) provide a tripartite distinction between "issues of ends (goals), issues of the relationship between means and ends ... and issues of success in adopting means" (p. 137). The authors conceptualize success as whether policy activities address the social problem at issue.

Previous research has examined implementation based on the sequence of events that follow from legislation, a "top-down" approach (Pressman \& Wildavsky, 1973). Policy implementation from a top-down approach focuses on State-based policy actors involved in designing laws and policies. Prior research characterizes such a topdown approach to implementation as emphasizing the goals of a policy and the means necessary for achieving those goals (Hill \& Hupe, 2008). In a top-down approach to implementation, State-based policy actors provide the means and maintain responsibility for achieving policy goals.

Alternatively, a "bottom-up" approach to policy implementation emphasizes the long-term interactions among key policy actors. Policy actors contribute to designing, promoting and ensuring compliance with policy objectives (Hill \& Hupe, 2008; Sabatier, 1986). Charlton and May (1995) analyzed bottom-up implementation processes in the context of international development. They argue that the role of non-governmental organizations (NGOs) have had a significant impact on the application and enforcement of international development policies and programs (pp. 241-242). According to these authors, NGOs actively cooperate with State actors in service delivery and in structuring policies and programs. Thus, adopting a bottom-up approach to examining implementation constitutes a "shift of normative concern away from questions about how those at the top can exert their wills" (Hill \& Hupe, 2008, p. 53). Hill and Hupe (2008) further pose an integrated framework for examining policy implementation, which, among other things, aims at examining the administrative layers that exist in a multi-dimensional approach to governance. They contend that administrative layers refer to different locations within a hierarchy where policy actors interact as part of a policy process. The authors recognize and argue that the actors involved in any administrative layer constitute a heterogeneous plurality. 
The prior literature suggests that policy implementation involves different administrative layers, which includes the top-down efforts of State actors and the bottom-up interactions among public and private sector actors. We employ research on policy implementation as an analytic lens to examine the tensions that exist between the administrative layers that are involved in ensuring web accessibility and promoting TPM.

\section{Social Regulation}

Research demonstrates that social regulation does not constitute unilateral action by the government alone (Levi-Faur, 2011, 2013). The design and implementation of social regulations spans the public-private sector divide and includes a multitude of actors engaged in formal and informal processes. In this way, social regulation is an approach to policy implementation that includes a wide range of State-based and non-State activities involving public and private sector actors. This conceptualization is supported by Levi-Faur (2011) and others such as Braithwaite $(2000,2006)$, Levi-Faur $(2013,2014)$, and Majone $(1993,1997,2010)$ who affirm that social regulation includes "the ex-ante bureaucratic legalization of prescriptive rules ... by social, business and political actors on other social, business and political actors" (p. 6). Thus, social regulation may include voluntary codes of practice, professional codes of conduct and guidelines established by non-State actors as well as more traditional State-based laws and policies (Levi-Faur, 2011).

Previous research has examined the role of non-State actors in designing and enforcing regulations (Levi-Faur, 2011). Levi-Faur (2011) characterizes hybrid forms of regulation that involve the cooperation of State and nonState actors. One form of hybrid regulation is multi-level regulation, where "regulatory authority is allocated to different levels of territorial tiers -supranational (global and regional), national, regional (domestic), and local" (p. 11). According to Levi-Faur (2011, p. 11), regulatory authority can be distributed "hierarchically" based on the authority of a specific agency. Conceptually, multi-level regulation resembles what Hill and Hupe (2008) refer to as administrative layers. Essentially these concepts refer to the variety of hierarchical levels and tiers where policy processes occur. For example, research has examined the hierarchical relationships between and among national and international State and non-State actors involved in governing and regulating the Internet (Hofmann, Katzenbach, \& Gollatz, 2016; Marsden, 2011; Mueller, 2009, 2010). Scholars characterize Internet governance as a multi-stakeholder system where interdependent actors coordinate policy processes within a plurality of international, national and regional administrative levels (Marsden, 2011; Mueller, 2009, 2010).

Abbott and Snidal (2009) likewise examine the roles and relationships among public and private actors involved in multi-level regulation. They argue that international businesses can challenge traditional State-based legislative models aimed at controlling non-State actors through "mandatory legal rules with monitoring and coercive enforcement" (p. 505). They characterize a new approach to multi-level regulation, characterized by "the central role of private actors ... and the correspondingly modest and largely indirect role of 'the state"' (p. 505). Abbott and Snidal (2009) first characterize the role of the State in these joint efforts as "an orchestrator rather than a top-down commander ... promoting and empowering a network of public, private-sector, and civil society actors and institutions" (p. 521). Second, they characterize regulatory authority in joint efforts for international regulation as "decentralized, with regulatory responsibilities shared among private actors as well as state agencies" (p. 524). Accordingly, decentralization is not only a regression of State-based authority, but also acts as a means for encouraging non-State actors to promote social outcomes (p. 525). In addition, many actors collaborate in multi-stakeholder arrangements and pursue complementary goals using complementary competencies (p. 526).

Levi-Faur (2011) characterizes these national and international relationships and partnerships among public private actors as a hybrid form of regulation referred to as "co-regulation." Co-regulation occurs when State and non-State actors share responsibility for the design and enforcement of social regulations: "[t]he particular scope of cooperation may vary as long as the regulatory arrangements are grounded in cooperative techniques and ... rests at least partly on public-private cooperation" (p. 10).

Social regulation thus involves different national and international public and private sector actors who collaborate to pursue policy goals. We next use research on social regulation as an analytic lens to examine the roles, relationships and involvement of policy actors in the different regulatory tiers involved in the implementation of laws and policies that aim to ensure web accessibility and promote the use of TPM. 


\section{Methods}

We examine the multidimensional relationships between law and policy aimed at promoting web accessibility and TPM through a multilevel case study of national and international law and policy in the United States. We use qualitative data and analyses, including a literature review and law and policy analysis to provide support for the case study. Previous research demonstrates that such case study approaches provide a useful means for examining a phenomenon in context, particularly where investigators have limited to no control over events (Yin, 2013). Thus, case studies provide a useful research design to understand interactions among different levels or tiers of law and policy design and implementation. George and Bennett (2005) describe case studies as an "instance [case] of a class of events [phenomenon]" (p. 18). Yin (2013) provides a description of case studies as empirical inquiries that "investigate a contemporary phenomenon in-depth and within its real-life context, especially when the boundaries between the phenomenon and context are not clearly evident" (p. 13). Case studies provide a holistic examination of the meaningful characteristics of real-life events and provide a useful design for understanding complex social phenomena (Yin, 2013).

The results of case studies allow investigators to expand and generalize theories (Boix \& Stokes, 2007; George \& Bennett, 2005; Mitchell, 1983; Yin, 2013). Rather than generalizing statistically by "enumerating frequencies," case studies generalize to "theoretical propositions" (Yin, 2013, pp. 35-40). Case studies aim to inform theory and models of policy implementation by evaluating theoretical assumptions and extending models of policy implementation and social regulation by identifying new and potential causal conditions and areas of exploration. This article uses the case study approach to examine a phenomenon - i.e., the intersection between two regulatory regimes - in a particular context - i.e., within and between multiple levels of governance. Essentially, this article examines the intersection between disability rights and intellectual property rights within multilevel governance systems by investigating a particular class of events - i.e., the implementation of web accessibility and TPM law and policy.

Publicly available law and policy documents provide data on the social regulatory approaches involved in promoting web accessibility and TPM. The present literature review draws from research in web accessibility and technology protection measures and publicly available law and policy documents. Sources include national and international laws, regulations, policies, government research and reports, standards and guidelines. The data sources used did not involve the actual collection, recording and storing of personal information, so no human subjects ethics approval was sought. It is beyond the scope of this article to conduct a systematic review of the literature - i.e., an exhaustive study of the literature relevant for answering a particular research question. Nonetheless, this article has searched relevant databases including Google Scholar and LexisNexis using keywords such as "web accessibility" and "technology protection measures" for research at the intersection of disability and intellectual property rights. Several hundred articles were reviewed from the millions of search results and relevant articles were identified until the results ceased to produce relevant research.

This article recognizes the significance of research related to the digital divide and property rights more broadly. However, this article has deliberately chosen to examine a concise niche of research related explicitly to web accessibility and TPM in order to provide a background for examining the broader theoretical assumptions drawn from models of policy implementation and social regulation.

\section{Investigating the Interaction Among Web Accessibility and Technology Protection Measures}

Research on web accessibility and TPM provides a useful basis for understanding the experiences of persons with disabilities in using digital media. We examine research on TPM as it applies to the experiences of persons with cognitive disabilities in particular, and do not systematically investigate all the technologies that make up TPM.

Public and private sector service providers have yet to ensure that persons with disabilities have full and equal access to web content (Bertot, Jaeger, \& Hansen, 2012; De Andrés et al., 2010; Green \& Huprich, 2009; Jaeger, 2004a, 2004b, 2008; Johnson \& Ruppert, 2002; Klein et al., 2003; Kuzma, 2010; Lazar et al., 2010; Olalere \& Lazar, 2011; Ritchie \& Blanck, 2003; Rubaii-Barrett \& Wise, 2008; Stewart, Narendra, \& Schmetzke, 2005; Tatomir \& Durrance, 2010; R. Williams \& Rattray, 2003; Yi, 2015; Yu, 2002). Web accessibility research has focused on the 
application of antidiscrimination laws (Blanck, 2014b; Easton, 2012, 2013a, 2013b; Noble, 2002; Schaefer, 2003; Wall \& Sarver, 2003; Wentz, Jaeger, \& Lazar, 2011). This line of study examines the legal basis for web accessibility and the disputes that have emerged from efforts to establish web accessibility as a legal obligation. In the United States, web accessibility remains a contested subject even more than twenty-five years following the introduction of the Americans with Disabilities Act (ADA) in 1990, and as amended in 2008 (Blanck, 2016b; Blanck, 2017).

Web accessibility research has investigated the use of standards, principles and guidelines to examine public perception, social participation and policy approaches related to web accessibility (Blanck, 2008; Easton, 2011; Jaeger \& Xie, 2009; Kelly et al., 2009; Yesilada, Brajnik, Vigo, \& Harper, 2014). After passage of the ADA, in the late 1990s, the World Wide Web Consortium (W3C) introduced the Web Content Accessibility Guidelines (WCAG), an international voluntary standard aimed at encouraging content providers to ensure web accessibility, which has particular relevance to people with cognitive impairments. WCAG consists of four principles for web accessibility including perceivable - i.e., that web content must be presented in a way that users can perceive; operable - i.e., that web content and navigation must be operable; understandable i.e., that information and navigation must be understandable; and robust - i.e., that web content must be compatible with a variety of technologies including assistive technologies.

Research on the experiences of persons with disabilities in using digital media also shows that TPM may act as a barrier to accessibility (Ellis \& Kent, 2011; Helberger et al., 2004; Kerscher \& Fruchterman, 2002; Kramer, 2007). Scholars have broadly claimed that copyright law and policy tends to favor content creators who determine who can use their work and how (Grodzinsky \& Bottis, 2007). Foroughi, Albin and Gillard (2002) discuss the side effects of TPMs and thus emphasize the need for balancing customer and business concerns. According to Ellis and Kent (2011), digital media creators have increasingly used technical tools to protect online content from copyright infringement. National and international laws have supported certain exceptions to copyright law that make it legal, for instance for libraries, to reproduce copyrighted works in accessible formats (Li, 2015; Papadopoulou, 2010; Rekas, 2013; Sganga, 2015; S. Williams, 2011; Zemer \& Gaon, 2015). However, scholars have argued that TPM limits the ability of libraries and persons with disabilities to convert digital media to accessible formats, even when conversion would be permitted under copyright law (Bae, Jeong, Shim, \& Kwak, 2007; Dillon, 2001; Ellis \& Kent, 2011; Morgan, 2003). This is because anti-circumvention laws in many countries make circumvention of TPM illegal, even if the user would otherwise be entitled to make use of the copyrighted content-including under laws that allow individuals with disabilities to create accessible format copies. Thus, the protection of digital content by TPM prevents unauthorized access and use of the content by the technologies that libraries use to reproduce accessible versions of the content. Some argue that TPM is not compliant with WCAG, and often is incompatible with the use of assistive technologies (Ellis \& Kent, 2011; Helberger et al., 2004; Kerscher \& Fruchterman, 2002; Kramer, 2007). Assistive technologies include any technologies used to "increase, maintain, or improve the functional capabilities of persons with disabilities" (ATIA, 2015), including applications for persons with cognitive disabilities (Gillespie, Best, \& O'Neill, 2012). Ellis and Kent (2011) point to the complex effect of legislation that makes circumventing TPM illegal. They suggest that the rights of copyright owners, penalties for copyright infringement, and laws criminalizing circumvention have the unintended consequence of creating barriers to digital media accessibility.

\section{Intersecting Rights and Obligations}

Legal regulation and enforcement of TPM is the product of interrelated international and domestic regulatory efforts in the United States. Domestic lobbies seeking protection of technological controls for access and content have used international venues to sidestep hurdles encountered in domestic legislative processes (Helfer, 2004). After obtaining international treaty commitments that required the introduction of legal protection of TPMs, some U.S. content owners lobbied for broad domestic legislation, which then propagated horizontally to other jurisdictions under similar treaty commitments. These commitments were bolstered by new treaties sought by the United States on a bilateral or plurlilateral basis.

This section discusses enactment of legal protections for copy and access controls in the United States as one example of multi-level governance. It then considers the impact that these developments have on individuals with cognitive disabilities. 


\section{Regime Shifting}

In the mid- to late-1980s, U.S. copyright owners began pressuring the U.S. government to take steps to address copyright infringement globally and to push for higher standards of protection abroad (Helfer, 2004). As Helfer (2004) explains, battles around patent protection in the World Intellectual Property Organization (WIPO) led the United States to be skeptical of using WIPO for such an effort. Having had success at raising intellectual property standards through bilateral trade agreements, the United States sought and achieved the inclusion of intellectual property issues as part of the World Trade Organization (WTO) in 1994 (Helfer, 2004). The WTO presented an attractive regime for several reasons, including increased leverage of the United States and the EU in that forum, the ability to link intellectual property protection with other areas of interest to developing countries and thus increase bargaining pressure, and the availability of dispute resolution mechanisms at the WTO that had the potential to provide the new intellectual property provisions with actual enforcement power (Helfer, 2004).

Having successfully linked intellectual property rights protection and enforcement to the trade regime, intellectual property rights holders began pursuing a range of measures to strengthen these rights. For the content industries, this included recognition of the protection of copyright in the digital realm as well as legal protection of TPM. Industry first sought to achieve these goals via national legislation, but when their efforts with the U.S. Congress failed, they took their case to Geneva-and specifically, to WIPO. WIPO, in turn, had been eager to play a role after observing the shift to lawmaking in the WTO (Dinwoodie, 2001), and was engaged in negotiation of two treaties governing copyright on the Internet: the WIPO Copyright Treaty (WCT) and the WIPO Performances and Phonograms Treaty (WPPT), both of which were opened for signature in 1996, and which entered into force in 2002.

Content owners sought and achieved inclusion of legal protection for TPM in these treaties (Rothchild, 2005; Samuelson, 1997). Article 11 of the WCT and Article 18 of the WPPT require ratifying states to provide legal protection for TPM by creating effective legal remedies against circumvention. Article 12 of the WCT and Article 19 of the WPPT require ratifying States to provide legal remedies for removing or altering rights management information and knowingly sharing copies for which that information had been removed. Article 15 of the 2012 Beijing Treaty on Audiovisual Performances also requires effective legal protection of TPMs.

Although technological protection measures themselves were not new, the obligations imposed by the WCT and the WPPT were revolutionary. Gwen Hinze explains (Hinze, 2006) that digital locks on software had been widely used but were abandoned "when it became clear that they were unpopular with customers and ineffective at preventing infringement" (Hinze, 2006, p. 780). Hinze adds, "What changed in 1996 with the adoption of the WCT and WPPT was that rightsholders' technological measures were-for the first time-required to be enforced by legal sanctions as a matter of international law. ... . It is hard to overstate the importance of this. Anticircumvention rules controlled by private rightsholders suddenly took precedence over copyright law, and the public policy values embodied in it" (Hinze, 2006, pp. 780-781).

\section{Shifting Between National and International Obligations}

Having achieved a victory in including legal protections for TPM in the WIPO copyright treaties, rightsholders were able to return to domestic lawmakers to push for changes in national law. Even prior to U.S. ratification in 1999, industry advocates argued that the United States must pass legislation that, among other things, created legal remedies for circumvention of TPMs to comply with its obligations were it to become a party to these two treaties.

Although it is not clear that additional legislation was in fact necessary to comply with the WIPO copyright treaties (Samuelson, 1999), lawmakers introduced and passed legislation in 1998 that was designed to bring the United States into compliance with the requirements of the WCT and the WPPT and thus enable ratification. The Digital Millennium Copyright Act (DMCA) introduced wide ranging changes to the U.S. Copyright Act, including many that go beyond what was required by the treaties (Hinze, 2006). 
Among those changes was Section 1201, which introduced provisions preventing circumvention of technological protection measures. Section 1201(a)(1)(A) provides: "No person shall circumvent a technological measure that effectively controls access to a work protected under this title [the Copyright Act]." Violation of this provision is subject to civil fines (including statutory damages) as well as criminal penalties. The DMCA prevents trafficking in circumvention technology, if the technology is marketed or primarily used for circumvention or to enable unauthorized copying (17 U.S.C. 1201(a)(2)(A)-(C); (Rothchild, 2005).

The DMCA does contain limited provisions that are aimed at protecting users' rights, including exemptions for reverse engineering, research on encryption, and security testing (17 U.S.C. 1201(d)-(j); (Nimmer, 2000, p. 703). The Librarian of Congress can create exemptions to the anti-circumvention ban after consultation if determining that users are being adversely affected by the anti-circumvention ban in their ability to make noninfringing use of copyrighted works. Making this determination allows the Librarian to exempt that class of works from the prohibition on circumvention of TPMS for a three year period (17 U.S.C. 1201(a)(1)(C)-(D)).

Once implemented in the DMCA, the strong version of anti-circumvention adopted by the United States propagated to other parts of the world through trade agreements. Some of these agreements "spell out the precise language of obligations, which typically mirrors the language of the DMCA" (Okediji, 2009, p. 2401). Thus, robust prohibitions on circumvention of technological protection measures were replicated in many jurisdictions.

Although the future of the Trans-Pacific Partnership (TPP), a trade treaty negotiated in 2015 by twelve countries, but now rejected by the Trump Administration in the United States, is uncertain, its provisions nonetheless exemplify the influence of the DMCA on international trade agreements. In 2017, the U.S. government published a memorandum stating that the U.S. would withdraw from the TPP. As of the writing of this article, the future of the TPP remains uncertain. Article 18.68 of the TPP obligates State Parties to "provide adequate legal protection and effective legal remedies against the circumvention of [TPM]." The TPP refers to TPM as "effective technological measure", which "means any effective technology, device, or component that, in the normal course of its operation, controls access to a protected work, performance, or phonogram, or protects copyright or related rights related to a work, performance or phonogram". The obligation to protect against TPM circumvention includes the manufacture, distribution or providing services for TPM circumvention. The TPP further obligates State Parties to "provide for criminal procedures and penalties to be applied if any person is found to have engaged willfully and for the purposes of commercial advantage or financial gain" in the manufacture, distribution or service provision of technologies for circumventing TPM.

However, the TPP contains an exception where States Parties "provide that the criminal procedures and penalties do not apply to a nonprofit library, museum, archive, educational institution, or public non-commercial broadcasting entity" or where those organizations have circumvented TPM "in good faith without knowledge that the conduct is prohibited." Article 18.66 of the TPP recognizes the necessity of balancing copyright law and policy with accessibility law and policy. Article 18.66 obligates States Parties to "achieve an appropriate balance in its copyright and related rights system ... by means of limitations or exceptions ... including ... giving due consideration to legitimate purposes such as ... facilitating access to published works for persons who are blind, visually impaired or otherwise print disabled." Presumably, those individual who are "otherwise print disabled" includes many persons with cognitive reading disabilities. Nonetheless, while the TPP recognizes the intersecting rights and obligations of copyright holders and persons with disabilities, national legislators and courts will need to determine whether TPM continues to act as a barrier to the use of digital media particularly for persons with cognitive disabilities.

\section{Exceptions for Individuals with Disabilities}

While provisions of the DMCA have not in fact been successful at ending or even slowing copyright infringement, they have "caused serious collateral damage to consumers, scientific researchers, competition and technological innovation" (Hinze, 2006, p. 782). In many instances, legal protections against circumvention prevent these users from using works in ways that do not violate copyright. In these instances, the users have not violated copyright, but may nonetheless be civilly or criminally liable for circumvention. 
Individuals with visual impairments and cognitive print disabilities are among those most negatively affected not only by TPMs, but also legal prohibitions on circumventing TPMs. In the United States, the Chafee Amendment to the U.S. Copyright Act (17 USC § 121) provides that it is not a violation of copyright "for an authorized entity to reproduce or to distribute copies or phonorecords of a previously published, nondramatic literary work if such copies or phonorecords are reproduced or distributed in specialized formats exclusively for use by blind or other persons with disabilities" (17 USC § 121(a)). Subsection (b) imposes some limitations on this exception, including that the copies produced shall "not be reproduced or distributed in a format other than a specialized format exclusively for use by blind or other persons with disabilities" (17 USC § 121(b)(1)(A)). Although ostensibly allowed to reproduce and distribute copyrighted works to create an accessible format copy under the Chafee Amendment as well as under preexisting principles of fair use (Cox, 2012), the DMCA prevents visually impaired individuals from circumventing access and copy controls on copyrighted works to engage in these non-infringing uses (Bertlesman, 2012; Hinze, 2006).

In response to these limitations, advocacy groups in the United States sought an exemption from the Librarian of Congress for circumvention of TPMs designed to enable non-infringing uses by individuals with disabilities. In 2003, the Librarian added an exemption for eBooks that "contain access controls" preventing read-aloud functions or the conversion of the book into an accessible format (37 C.F.R. § 201.40(b)(4) (2003). This exemption was subsequently revised in 2012 to be more technology neutral (37 C.F.R. § 201.40(b)(1) (2012)), and was renewed in 2015 (37 C.F.R. § 201.40(2) (2015)).

Yet the Library of Congress process alone is not sufficient to address the broader public interest impact of the anti-circumvention provisions of the DMCA, either in general or for individuals with cognitive or print disabilities (Reichman, Dinwoodie, \& Samuelson, 2007). In addition to requiring reapplication every three years and being limited to particular classes of work, the process does not allow the Librarian to create exemptions to the ban on trafficking in tools (Hinze, 2006; Reichman et al., 2007), which means limited or no access to the tools needed to circumvent TPMs to create accessible copies.

\section{IP Resistance and the Marrakesh Treaty}

Increasingly, strong intellectual property standards worldwide driven by multilateral and bilateral trade treaties provoked considerable opposition from those who saw these standards as harming the public interest. Longer copyright terms and more powerfully enforced copyright laws, for example, risked harming the ability of users to create and share cultural materials and circumscribing the scope of exceptions and limitations that had long existed for the benefit of education and expressive exchange (see, e.g., Boyle, 2003; Chon 2007; Gervais 2008; Kapczynski 2012). United Nations human rights bodies began to attend to the human rights consequences of strong intellectual property laws (Helfer, 2006; Helfer \& Austin, 2011). Some scholars argued that the system of intellectual property protection itself was flawed, and that financing innovation through market mechanisms would inevitably harm the public interest by failing to produce the range of public goods needed by society (Kapczynski, 2012; Shaver, 2010, 2014).

In particular, many argued that the copyright system, both copyright itself as well as the protection of copyright through legal protection of TPMs, harmed the general interests of individuals with disabilities. Many pointed to the "book famine"-the fact that between one and five percent of all books worldwide (one percent in developing nations, five percent in developed nations) are available in formats accessible to individuals with print disabilities (Ayoubi, 2015; Kaminski \& Yanisky-Ravid, 2013). The lack of books in accessible formats limits the ability of print-disabled individuals to enjoy a wide variety of human rights, including the rights to freedom of expression, to education, and to participate in cultural life (Helfer, 2006). Article 30(3) of the CRPD, for example, requires ratifying States "to ensure that laws protecting intellectual property rights do not constitute an unreasonable or discriminatory barrier to access by persons with disabilities to cultural materials."

In response to these perceived deficiencies and imbalances in international copyright law, scholars and advocates, as well as developing countries, began pushing for IP policies attuned to the public interest, including international instruments that would protect the public interest values inherent in copyright that had been under pressure by international trade treaties, including instruments protecting exceptions and limitations to copyright (Hugenholtz \& Okediji, 2012; Okediji, 2006; Okedui, 2000); see generally Kapczynski (2012). Efforts 
focused on the pursuit of specific instruments mandating exceptions and limitations; for example, on an instrument facilitating exceptions and limitations to copyright for libraries or for the blind (Kaminski \& YaniskyRavid, 2013). Although expansions in copyright law triggered a renewed focus on this issue, Cox notes that efforts to create an international instrument creating exceptions to copyright for the benefit of individuals with disabilities have a much longer history, dating back to at least 1982 (Cox, 2012). With respect to TPMs, scholars advocated for the creation of reverse "notice-and-takedown" regimes that would require rights-holders to remove TPMs if informed by users of the user's intent to make public interest use of the work (Reichman et al., 2007).

The proposal that eventually garnered support was an instrument on exceptions and limitations to copyright for individuals with print disabilities. WIPO took the lead on efforts to create a new treaty that would require states to create exceptions to copyright for individuals with print disabilities to enable these individuals to create and share accessible format copies, including across borders (Kaminski \& Yanisky-Ravid, 2013). The result was the Marrakesh Treaty to Facilitate Access to Published Words for Persons Who are Blind, Visually Impaired, or Otherwise Print Disabled, which came into force on September 30, 2016 with the thirtieth ratification of the treaty. The treaty uses the legal and policy tools of copyright to achieve its human rights goals of enabling printdisabled individuals to access books and other cultural materials (Helfer, Land, Okediji, \& Reichman, 2017).

The conclusion of the Marrakesh Treaty represents another shift to an international forum to address limitations of domestic law. Although exceptions and limitations for the blind are among the most longstanding national exceptions to copyright around the world, many countries nonetheless lacked such exceptions, and there was considerable variation among those that did have these provisions in national law (Helfer et al., 2017; Kaminski \& Yanisky-Ravid, 2013). Moreover, because of the territoriality of copyright, it was not possible for accessible format copies created in one jurisdiction to be shared with print-disabled individuals in other jurisdictions (Helfer et al., 2017; Kaminski \& Yanisky-Ravid, 2013). The Marrakesh Treaty thus is aimed at harmonizing exceptions across national jurisdictions including exceptions that permit the export of accessible format copies.

The Marrakesh Treaty includes a provision requiring states to ensure that national laws protecting TPMs do not prevent individuals with print disabilities from enjoying their rights under the treaty. Article 7 of the Marrakesh Treaty provides that ratifying states "shall take appropriate measures, as necessary, to ensure that when they provide adequate legal protection and effective legal remedies against the circumvention of effective technological measures, this legal protection does not prevent beneficiary persons from enjoying the limitations and exceptions provided for in this Treaty." Thus, states have to ensure that TPMs do not prevent individuals with print disabilities (broadly defined to include cognitive disability, Blanck, 2014a) from making use of the exceptions and limitations that ratifying states are required to create to allow individuals with print disabilities to create, use and share accessible format works of books and other cultural materials without a license from the copyright owner.

\section{Discussion}

This study yields several contributions to existing literature. First, it provides support for the claim that regulatory conflicts sometime may not only undermine, but also promote, policy outcomes (see, e.g., Helfer 2004). Interaction between regulatory regimes focused on extending the use of TPMs on the one hand and ensuring web accessibility for persons with disabilities on the other have resulted in conflict between rights and obligations created by different administrative layers. Intellectual property rights-holders subsequently leveraged international treaty-making processes to promote stronger intellectual property rights in national systems. This, in turn, provoked a range of human rights and disability rights advocates to advocate for international and national lawmaking designed to curb the excesses of overly strong IP rules. Rather than undermining regulatory goals, this indicates that conflict may play a generative role, providing opportunities for policy actors to articulate competing goals and present legal arguments aimed at reconciling and harmonizing these goals.

Second, our findings indicate that "top down" and "bottom up" approaches to regulation are not only regulatory alternatives, but also act as complements. In contrasting "top down" and "bottom up" regulatory approaches, existing literature on multilevel governance has neglected the extent to which these approaches interact to 
produce policy outcomes that differ from either approach alone. Implementation of web accessibility and copyright law and policy involves different administrative layers, where policy actors simultaneously aim to "exert their wills" from the top-down and involve long-term interactions among public and private sector actors. This is in fact the product of the interaction between layers.

The Marrakesh Treaty illustrates how "top down" interventions also promote "bottom up" solutions. The treaty is unique among regulatory efforts at the intersection of human rights and IP because it explicitly creates legal, policy, and institutional bridges between these regimes. It integrates the principles of participation and consultation under the CRPD into IP policy making around the accessibility of books and other cultural materials. The Treaty therefore provides a basis for involving intellectual property rights-holders and individuals with disabilities in conversations around how to reconcile these competing regulatory aims of intellectual property and disability rights legislation.

The CRPD contains several obligations for States Parties to ensure the political participation of persons with disabilities. Article 29, obligates States Parties to promote the full and effective participation of persons with disabilities in public affairs, including the forming and joining representative organizations of persons with disabilities at the international, national, regional and local levels. This obligation supports Article 4, which requires States Parties to consult with and actively involve persons with disabilities through their representative organizations in the design and implementation of relevant law and policy. Finally, Article 32, obligates States Parties to promote international cooperation between States, regional organizations, and civil society, including organizations of persons with disabilities.

The Marrakesh Treaty integrates the CRPD's principles of participation and consultation into IP lawmaking in three ways. As a legal matter, it references the CRPD in its Preamble, providing a basis for drawing on the CRPD as a source of authority in interpreting and implementing the provisions of the Marrakesh Treaty (Helfer et al. 2017). As a practical matter, many of the States that ratify the Marrakesh Treaty will also be parties to the CRPD, and will want to reconcile their obligations under these treaties. Finally, States may also find it efficient to rely on the capacity and expertise of established institutions charged with responsibility for human rights matters, such as national human rights institutions, in implementing and interpreting the treaty. In these ways, the Marrakesh Treaty provides a basis for involving domestic policy actors and persons with disabilities in discussions around web accessibility and TPMs (Helfer et al. 2017)

To ensure consistency among their international commitments and to achieve the objectives of the Marrakesh Treaty, States that ratify that treaty will have an obligation to consult with and actively involve persons with disabilities, through their representative organizations, in the design and implementation of those policies. The policies that result will more likely reflect their interests and needs and thus approximate a balance of the obligations of copyright and accessibility. Promoting participation of persons with disabilities in the design and implementation of national and international copyright law and policy is thereby likely to support the harmonization of law and policy promoting TPM with law and policy ensuring web accessibility.

\section{Conclusion}

This article began by asking how different levels of governance may act to ensure and support the rights of persons with cognitive disabilities and web content publishers. The results suggest that different regulatory regimes (i.e., regimes aimed at promoting the rights of content publishers and the rights of persons with cognitive disabilities) interact with and respond to the behaviors of policy actors in national and international levels of governance. More specifically, the results show that the conflicting rights and obligations enshrined in the CRPD, national disability antidiscrimination law and national and international intellectual property law provides an opportunity to integrate top-down governance efforts - i.e., in national and international administrative layers - with the bottom-up advocacy efforts of disability rights organizations and market-based interests of intellectual property rights-holders. This complex interaction among State and non-State actors within and across multiple layers of governance has produced the Marrakesh Treaty, which represents an integrated effort among rights advocates and intellectual property rights-holders aimed at reconciling and harmonizing the rights of persons with disabilities on one hand with the intellectual property rights of market actors on the other. 
The responsive and interactive effect of the shifting regulatory regimes further suggests that advocates will strategically select a venue as part of a long-term approach to promoting their agenda. For example, copyright owners have advocated for increasingly stricter protections of TPM and shifted their efforts among international organizations and between national and international levels of governance. Disability rights activists have responded accordingly to the efforts of copyright owners by advocating for exceptions on national and international levels of governance.

In relation to persons with cognitive disabilities, the intersecting rights and obligations of copyright and web accessibility law and policy have yet to integrate fully. There remain considerable unique and complementary barriers that persons with cognitive disabilities experience using digital media as compared to those with sensory impairments. Though research has yet to explore fully the experiences of persons with cognitive disabilities using TPM, the strict use of TPM may be particularly incompatible with principles of web content accessibility for persons with cognitive disabilities. Future research must examine the use of TPM by persons with cognitive disabilities in an effort to understand whether and to what extent copyright exceptions, under the Marrakesh Treaty and national legislation such as the Chafee Amendment, provide full and effective access to digital media on an equal basis.

This article recognizes the analytic and practical challenges to examining a complex phenomenon with many possible causes and many possible outcomes, such as the use of TPM by persons with cognitive disabilities. This article, nonetheless, argues that future research should begin to formalize research methodologies and theoretical and conceptual frameworks, and synthesize the relevant literature in an attempt to prepare a foundation for future research, which may begin to provide evidence on the usability and accessibility of TPM for persons with cognitive disabilities.

Nonetheless, ratification and implementation of the Marrakesh Treaty provides an important basis for moving forward in reconciling intellectual property rights and web accessibility. In promoting the participation of persons with cognitive and other disabilities in the development of national intellectual property regulations, the treaty represents an important step forward in balancing these rights and obligations. Future research must examine the "bottom up" approach facilitated by the Marrakesh Treaty with other approaches such as the TIGAR (Trusted Intermediary Global Accessible Resources). Service, an initiative hosted by WIPO and promoted by the publishing industry, in terms of their respective abilities to promote long-term interactions among public and private sector actors.

With ever-present technological advances, future researchers and practitioners should continue to investigate options for increasing the accessibility of TPMs. For example, future research may examine the feasibility of developing TPMs that simultaneously protect intellectual property while also allowing digital content to deploy assistive technologies. National and supranational governments should promote the rights of web content publishers and persons with cognitive and other disabilities by ensuring the harmonization of laws promoting TPM with laws ensuring web accessibility. One crucial means with which State actors may further the harmonization of web accessibility and copyright laws is to substantively involve persons with disabilities in the design and implementation of laws promoting TPM, such as through ratification and implementation of the CRPD and the Marrakesh Treaty.

\section{References}

Abbott, K., \& Snidal, D. (2009). Strengthening international regulation through transnational new governance: Overcoming the orchestration deficit. Vanderbilt Journal of Transnational Law, 42(2), 501-578.

ATIA. (2015). What is Assistive Technology? How is it funded? Retrieved from

http://www.atia.org/i4a/pages/index.cfm?pageid=3859

Ayoubi, L. (2015). Marrakesh Treaty: fixing international copyright law for the benefit of the visually impaired persons. NZJPIL, 13, 255. 
Bae, K.-J., Jeong, Y.-S., Shim, W.-S., \& Kwak, S.-J. (2007). The ubiquitous library for the blind and physically handicapped-A case study of the LG Sangnam Library, Korea. IFLA journal, 33(3), 210-219.

https://doi.org/10.1177/0340035207083302

Bertlesman, M. (2012). The fight for accessible formats: Technology as a catalyst for a world effort to improve accessibility domestically. Syracuse Sci. \& Tech. L. Rep., 27, 26-162.

Bertot, J. C., Jaeger, P., \& Hansen, D. (2012). The impact of polices on government social media usage: Issues, challenges, and recommendations. Government Information Quarterly, 29(1), 30-40.

https://doi.org/10.1016/j.giq.2011.04.004

Bickenbach, J. E., Chatterji, S., Badley, E. M., \& Ustün, T. B. (1999). Models of disablement, universalism and the international classification of impairments, disabilities and handicaps. Social Science \& Medicine, 48, 1173-1187. https://doi.org/10.1016/S0277-9536(98)00441-9

Beyene, W. (2016). Resource discovery and universal access: understanding enablers and barriers from the user perspective. Studies in Health Technology and Informatics, 229. https://doi.org/10.3233/978-1-61499-684-2-556

Blanck, P. (2008). Flattening the (inaccessible) cyberworld for people with disabilities. Assistive technology: The official journal of RESNA, 20(3), 175-180. https://doi.org/10.1080/10400435.2008.10131944

Blanck, P. (2014a). eQuality: The struggle for web accessibility by persons with cognitive disabilities. New York: Cambridge University Press.

Blanck, P. (2014b). The struggle for web equality by persons with cognitive disabilities. Behavioral Sciences \& the Law, 32(1), 4-32. https://doi.org/10.1002/bsl.2101

Blanck, P. (2016a). ADA at 25 and persons with cognitive disabilities: From action to inclusion. Inclusion, 4(1), 1-5. https://doi.org/10.1352/2326-6988-4.1.1

Blanck, P. (2016b). The First "A" in the ADA: And 25 more "A"s toward equality for Americans with disabilities. Inclusion, 4(1), 46-51. https://doi.org/10.1352/2326-6988-4.1.46

Blanck, P. (2017). eQuality: The right to the web. In P. Blanck \& E. Flynn (Eds.), Routledge handbook of disability law and human rights (pp. 166-194). London: Taylor \& Francis Group.

Blanck, P. \& Flynn, E. (Eds.) (2017). Routledge Handbook of Disability Law and Human Rights, Taylor \& Francis Group, London, UK.

Blaska, J. (1993). The power of language: Speak and write using "person first". Perspectives on Disability, 25-32.

Boix, C., \& Stokes, S. C. (2007). Introduction. In C. Boix \& S. C. Stokes (Eds.), The Oxford handbook of comparative politics (pp. 3-25). Oxford; New York: Oxford University Press.

Boyle, J. (2003). The second enclosure movement and the construction of the public domain. Law and Contemporary Problems, 66(1/2), 33-74.

Braithwaite, J. (2000). The new regulatory state and the transformation of criminology. British Journal of Criminology, 40, 222-238. https://doi.org/10.1093/bjc/40.2.222

Braithwaite, J. (2006). The regulatory state? In R. A. W. Rhodes, S. A. Binder, \& B. A. Rockman (Eds.), The Oxford handbook of political institutions (pp. 407-430). Oxford; New York: Oxford University Press.

Charlton, R., \& May, R. (1995). NGOs, politics, projects and probity: A policy implementation perspective. Third World quarterly, 16, 237-255. http://dx.doi.org/10.1080/01436599550036112

Chon, M. (2007). Intellectual property from below: Copyright and capability for education. UC Davis Law Review, 40, 803-854.

Cox, K. L. (2012). The right to read for blind or disabled persons. Landslide Magazine: A Publication of the ABA Section of Intellectual Property Law, 4(5), 32. 
Dawe, M. (2006). Desperately seeking simplicity: How young adults with cognitive disabilities and their families adopt assistive technologies. In Proceedings of the SIGCHI conference on Human Factors in computing systems (pp. 1143-1152). New York, NY: ACM.

De Andrés, J., Lorca, P., \& Martínez, A. B. (2010). Factors influencing web accessibility of big listed firms: An international study. Online Information Review, 34(1), 75-97. https://doi.org/10.1108/14684521011024137

Dillon, D. (2001). E-books: The University of Texas experience, part 1. Library Hi Tech, 19(2), 113-125. https://doi.org/10.1108/07378830110394826

Dinwoodie, G. B. (2001). Architecture of the international intellectual property system. Chi.-Kent L. Rev., 77, 9931014.

Easton, C. (2011). The web content accessibility guidelines 2.0: An analysis of industry self-regulation. International Journal of Law and Information Technology, 19(1), 74-93. https://doi.org/10.1093/ijlit/eaq015

Easton, C. (2012). Revisiting the law on website accessibility in the light of the UK's equality act 2010 and the United Nations convention on the rights of persons with disabilities. International Journal of Law and Information Technology, 20(1), 19-47. https://doi.org/10.1093/ijlit/ear015

Easton, C. (2013a). An examination of the Internets development as a disabling environment in the context of the social model of disability and anti-discrimination legislation in the UK and USA. Universal Access in the Information Society, 12(1), 105-114.

Easton, C. (2013b). Website accessibility and the European Union: Citizenship, procurement and the proposed Accessibility Act. International Review of Law, Computers \& Technology, 27(1-2), 187-199.

https://doi.org/10.1080/13600869.2013.764135

EFHOH. (2017). What does "hard of hearing" mean? Retrieved from http://www.efhoh.org/about_us

Ellis, K., \& Kent, M. (2011). Disability and new media. Routledge.

Foroughi, A., Albin, M., \& Gillard, S. (2002). Digital rights management: A delicate balance between protection and accessibility. Journal of Information Science, 28, 389-395.

Friedman, M. G., \& Bryen, D. N. (2007). Web accessibility design recommendations for people with cognitive disabilities. Technology and Disability, 19, 205-212.

George, A. L., \& Bennett, A. (2005). Case studies and theory development in the social sciences. Cambridge, Mass.: MIT Press.

Gervais, D. J. (2008). Making copyright whole: A principled approach to copyright exceptions and limitations. U. OTTAWA L. \& TECH. J., 5, 1-22.

Gillespie, A., Best, C., \& O'Neill, B. (2012). Cognitive function and assistive technology for cognition: A systematic review. Journal of the International Neuropsychological Society, 18(01), 1-19.

https://doi.org/10.1017/S1355617711001548

Green, R. A., \& Huprich, J. (2009). Web accessibility and accessibility instruction. Journal of Access Services, 6(1-2), 116-136. https://doi.org/10.1080/15367960802247825

Grodzinsky, F. S., \& Bottis, M. C. (2007). Private use as fair use: Is it fair? ACM SIGCAS Computers and Society, 37, 1124. https://doi.org/10.1145/1327325.1327326

Helberger, N., Kerényi, K., Krings, B., Lambers, R., Orwat, C., Riehm, U., ... Dufft, N. (2004). Digital rights management and consumer acceptability: A multi-disciplinary discussion of consumer concerns and expectations.

Helfer, L. R. (2004). Regime shifting: The TRIPs agreement and new dynamics of international intellectual property lawmaking. Yale J. Int'l L., 29, 1-83.

Helfer, L. R. (2006). Toward a human rights framework for intellectual property. UC Davis L. Rev., 40, 971-1020. 
Helfer, L. R., \& Austin, G. W. (2011). Human rights and intellectual property: Mapping the global interface: Cambridge University Press.

Helfer, L. R., Land, M. K., Okediji, R. L., \& Reichman, J. H. (2017). The world blind union guide to the Marrakesh Treaty. Oxford: Oxford University Press.

Hill, M., \& Hupe, P. (2008). Implementing public policy: An introduction to the study of operational governance. London: Sage.

Hinze, G. (2006). Brave new world, ten years later: Reviewing the impact of policy choices in the implementation of the WIPO internet treaties' technological protection measure provisions. Case W. Res. L. Rev., 57, 779-821.

Hofmann, J., Katzenbach, C., \& Gollatz, K. (2016). Between coordination and regulation: Finding the governance in Internet governance. New Media \& Society. Advanced online publication.

https://doi.org/10.1177/1461444816639975

Hugenholtz, P. B., \& Okediji, R. (2012). Conceiving an international instrument on limitations and exceptions to copyright. Study supported by the Open Society Institute (OSI), March, 6(2008).

Hughes, B. (2007). Being disabled: Towards a critical social ontology for disability studies. Disability \& Society, 22, 673-684. https://doi.org/10.1080/09687590701659527

Jaeger, P. (2004a). Beyond Section 508: The spectrum of legal requirements for accessible e-government web sites in the United States. Journal of Government Information, 30, 518-533. https://doi.org/10.1016/S1352-

0237(04)00057-7

Jaeger, P. (2004b). The social impact of an accessible e-democracy. Journal of Disability Policy Studies, 15, 19-26. https://doi.org/10.1177/10442073040150010401

Jaeger, P. (2008). User-centered policy evaluations of section 508 of the rehabilitation act: Evaluating egovernment web sites for accessibility for persons with disabilities. Journal of Disability Policy Studies, 19, $24-33$. https://doi.org/10.1177/1044207308315274

Jaeger, P., \& Xie, B. (2009). Developing online community accessibility guidelines for persons with disabilities and older adults. J. Disabil. Policy Stud. Journal of Disability Policy Studies, 20(1), 55-63.

https://doi.org/10.1177/1044207308325997

Johnson, A., \& Ruppert, S. (2002). An evaluation of accessibility in online learning management systems. Library Hi Tech, 20, 441-451. https://doi.org/10.1108/07378830210452640

Kaminski, M. E., \& Yanisky-Ravid, S. (2013). Marrakesh Treaty for visually impaired persons: Why a treaty was preferable to soft law. U. Pitt. L. Rev., 75, 255-300.

Kapczynski, A. (2012). The cost of price: Why and how to get beyond intellectual property internalism. UCLA Law Review, 59, 970-1026.

Kelly, B., Sloan, D., Brown, S., Seale, J., Lauke, P., Ball, S., \& Smith, S. (2009). Accessibility 2.0: Next steps for web accessibility. Journal of Access Services, 6, 265-294. https://doi.org/10.1080/15367960802301028

Kenny, L., Hattersley, C., Molins, B., Buckley, C., Povey, C., \& Pellicano, E. (2016). Which terms should be used to describe autism? Perspectives from the UK autism community. Autism, 20, 442-462.

https://doi.org/10.1177/1362361315588200

Kerscher, G., \& Fruchterman, J. (2002). The soundproof book: Exploration of rights conflict and access to commercial eBooks for people with disabilities. First Monday, 7(6). https://doi.org/10.5210/fm.v7i6.959

Klein, D., Myhill, W., Hansen, L., Asby, G., Michaelson, S., \& Blanck, P. (2003). Electronic doors to education: Study of high school website accessibility in lowa. Behavioral Sciences \& The Law, 21, 27-50.

https://doi.org/10.1002/bsl.521

Kramer, E. F. (2007). Digital rights management: Pitfalls and possibilities for people with disabilities. Journal of Electronic Publishing, 10(1). http://dx.doi.org/10.3998/3336451.0010.106 
Kreps, D., \& Goff, M. (2015). Code in action: Closing the black box of WCAG 2.0, A Latourian reading of Web accessibility. First Monday, 20(9). https://doi.org/10.5210/fm.v20i9.6166

Kuzma, J. M. (2010). Accessibility design issues with UK e-government sites. Government Information Quarterly, 27, 141-146. https://doi.org/10.1016/j.giq.2009.10.004

Laureys, S., Celesia, G. G., Cohadon, F., Lavrijsen, J., León-Carrión, J., Sannita, W. G., . . Zeman, A. (2010). Unresponsive wakefulness syndrome: a new name for the vegetative state or apallic syndrome. BMC Medicine, 8(1), 68. https://doi.org/10.1186/1741-7015-8-68

Lazar, J., Jaeger, P., Adams, A., Angelozzi, A., Manohar, J., Marciniak, J., ... Walsh, J. (2010). Up in the air: Are airlines following the new DOT rules on equal pricing for people with disabilities when websites are inaccessible? Government Information Quarterly, 27, 329-336. https://doi.org/10.1016/j.giq.2010.04.005

Levi-Faur, D. (2011). Regulation and regulatory governance. In D. Levi-Faur (Ed.), Handbook on the Politics of Regulation (pp. 3-21). Cheltenham: Edward Elgar Pub.

Levi-Faur, D. (2013). The odyssey of the regulatory state: From a "thin" monomorphic concept to a "thick" and polymorphic concept. Law and Policy, 35(1-2), 29-50. https://doi.org/10.1111/lapo.12000

Levi-Faur, D. (2014). The Welfare State: A regulatory perspective. Public Admin Public Administration(4), n/a.

$\mathrm{Li}$, J. (2015). Facilitating access to digital content for the print disabled: The need to expand exemptions to copyright laws. Intellectual Property Journal, 27(3), 355-384.

Majone, G. (1993). The European community between social policy and social regulation. JCMS: Journal of Common Market Studies, 31, 153-170. https://doi.org/10.1111/j.1468-5965.1993.tb00455.x

Majone, G. (1997). From the positive to the regulatory state: Causes and consequences of changes in the mode of governance. Journal of Public Policy, 17, 139-167. https://doi.org/10.1017/S0143814X00003524

Majone, G. (2010). The transformation of the regulatory state. Osservatorio sull'Analisi di Impatto della Regolazione. Marsden, C. T. (2011). Internet co-regulation: European law, regulatory governance and legitimacy in cyberspace. Cambridge University Press.

Mitchell, J. C. (1983). Case and situation analysis. The Sociological Review, 31, 187-211. https://doi.org/10.1111/j.1467-954X.1983.tb00387.x

Morgan, G. (2003). A word in your ear: Library services for print disabled readers in the digital age. The Electronic Library, 21, 234-239. https://doi.org/10.1108/02640470310480489

Mueller, M. L. (2009). Ruling the root: Internet governance and the taming of cyberspace: MIT press.

Mueller, M. L. (2010). Networks and states: The global politics of Internet governance: MIT press.

NAD. (2017). Community and culture - Frequently asked questions. Retrieved from

https://www.nad.org/resources/american-sign-language/community-and-culture-frequently-asked-questions/

Nimmer, D. (2000). A riff on fair use in the Digital Millennium Copyright Act. University of Pennsylvania Law Review, 148, 673-742. https://doi.org/10.2307/3312825

Noble, S. (2002). Web access and the law: A public policy framework. Library Hi Tech, 20, 399-405. https://doi.org/10.1108/07378830210452604

Okediji, R. (2006). The international copyright system: Limitations, exceptions and public interest considerations for developing countries: International Centre for Trade and Sustainable Development (ICTSD).

Okediji, R. (2009). The regulation of creativity under the WIPO Internet Treaties. Minnesota Legal Studies Research Paper (09-30).

Okedui, R. (2000). Toward an international fair use doctrine. Colum. J. Transnat'l L., 39, 75. 
Olalere, A., \& Lazar, J. (2011). Accessibility of U.S. federal government home pages: Section 508 compliance and site accessibility statements. Government Information Quarterly, 28, 303-309.

https://doi.org/10.1016/j.giq.2011.02.002

Oliver, M., \& Barnes, C. (2012). The new politics of disablement. Houndmills, Basingstoke; New York, NY: Palgrave Macmillan.

Papadopoulou, M. D. (2010). Copyright exceptions and limitations for persons with print disabilities: The innovative Greek legal framework against the background of the international and European developments.

Pressman, J. L., \& Wildavsky, A. B. (1973). Implementation: How great expectations in Washington are dashed in Oakland: or, Why it's amazing that Federal programs work at all, this being a saga of the Economic Development Administration as told by two sympathetic observers who seek to build morals on a foundation of ruined hopes. Berkeley, Calif.: University of California Press.

Reichman, J. H., Dinwoodie, G. B., \& Samuelson, P. (2007). A reverse notice and takedown regime to enable public interest uses of technically protected copyrighted works. Berkeley Technology Law Journal, 22, 981-1060.

Rekas, A. (2013). Tracking the progress of the proposed WIPO Treaty on exceptions and limitations to copyright to benefit persons with print disabilities. In L. Waddington, G. Quinn, \& E. Flynn (Eds.), European yearbook of disability law, Vol. 4 (pp. 45-72). Intersentia.

Ritchie, H., \& Blanck, P. (2003). The promise of the internet for disability: A study of on-line services and web site accessibility at centers for independent living. Behavioral sciences \& the law., 21, 5-26.

https://doi.org/10.1002/bsl.520

Rothchild, J. (2005). Economic analysis of technological protection measures. Oregon Law Review, 84, 489.

Rubaii-Barrett, N., \& Wise, L. R. (2008). Disability access and e-government: An empirical analysis of state practices. J. Disabil. Policy Stud. Journal of Disability Policy Studies, 19, 52-64.

https://doi.org/10.1177/1044207307311533

Sabatier, P. A. (1986). Top-down and bottom-up approaches to implementation research: A critical analysis and suggested synthesis. Journal of Public Policy, 6(01). https://doi.org/10.1017/S0143814X00003846

Samuelson, P. (1997). The US digital agenda at WIPO. VA. J. Int'I L., 37, 369.

Samuelson, P. (1999). Intellectual property and the digital economy: Why the anti-circumvention regulations need to be revised. Berkeley Technology Law Journal, 14, 519-566.

Schaefer, K. (2003). E-space inclusion: A case for the americans with disabilities act in cyberspace. Journal of Public Policy \& Marketing, 22, 223-227. https://doi.org/10.1509/jppm.22.2.223.17638

Sganga, C. (2015). Disability, right to culture and copyright: Which regulatory option? International Review of Law, Computers \& Technology, 29, 88-115. http://dx.doi.org/10.1080/13600869.2015.1055658

Shaver, L. (2010). Right to Science and Culture, The. Wis. L. Rev., 121.

Shaver, L. (2014). Copyright and Inequality. Lea Shaver, 92.

Sinclair, J. (2013). Why I dislike "person first" language. Autonomy, the Critical Journal of Interdisciplinary Autism Studies, 1(2).

Small, J., Schallau, P., Brown, K., \& Appleyard, R. (2005). Web accessibility for people with cognitive disabilities. In CHI'05 Extended Abstracts on Human factors in Computing Systems (pp. 1793-1796). New York, NY: ACM.

Stewart, R., Narendra, V., \& Schmetzke, A. (2005). Accessibility and usability of online library databases. Library Hi Tech, 23, 265-286. https://doi.org/10.1108/07378830510605205

Tatomir, J., \& Durrance, J. C. (2010). Overcoming the information gap: Measuring the accessibility of library databases to adaptive technology users. Library Hi Tech, 28, 577-594.

https://doi.org/10.1108/07378831011096240 
United Nations. (2006). Convention on the Rights of Persons with Disabilities and Optional protocol (9789211302615 9211302617). Retrieved from https://www.un.org/development/desa/disabilities/convention-on-the-rights-ofpersons-with-disabilities.html

Vanderheiden, G. C., Treviranus, J., Usero, J. A. M., Bekiaris, E., Gemou, M., \& Chourasia, A. O. (2012). AutoPersonalization: Theory, practice and cross-platform implementation. In Proceedings of the Human Factors and Ergonomics Society Annual Meeting (pp. 926-930).

Vaughan, C. E. (1997). People-first language: An unholy crusade. Retrieved from http://www.blind.net/aphilosophy-of-blindness/individual-articles/people-first-language.html

W3C. (2016). Personalization and user preferences. Retrieved from https://w3c.github.io/coga/issuepapers/personalization-preferences.html

Wall, P. S., \& Sarver, L. (2003). Disabled student access in an era of technology. Internet and Higher Education, 6 , 277-284. https://doi.org/10.1016/S1096-7516(03)00046-0

WBU. (2017). About WBU. Retrieved from http://www.worldblindunion.org/English/about-

wbu/Pages/default.aspx

Wentz, B., Jaeger, P., \& Lazar, J. (2011). Retrofitting accessibility: The legal inequality of after-the-fact online access for persons with disabilities in the United States. First Monday, 16(11). https://doi.org/10.5210/fm.v16i11.3666

WFD. (2017). Our mission, our values, our people. Retrieved from https://wfdeaf.org/who-we-are/ourphilosophy/

Williams, R., \& Rattray, R. (2003). An assessment of Web accessibility of UK accountancy firms. Managerial Auditing Journal, 18, 710-716. https://doi.org/10.1108/02686900310500460

Williams, S. (2011). Closing in on the light at WIPO: Movement Towards a copyright treaty for visually impaired persons and intellectual property movements. U. Pa. J. Int'I L., 33, 1035-1074.

Yesilada, Y., Brajnik, G., Vigo, M., \& Harper, S. (2014). Exploring perceptions of web accessibility: A survey approach. Behaviour \& Information Technology, 34, 119-134. https://doi.org/10.1080/0144929x.2013.848238

Yi, Y. J. (2015). Compliance of Section 508 in public library systems with the largest percentage of underserved populations. Government Information Quarterly, 32(1), 75-81. https://doi.org/10.1016/j.giq.2014.11.005

Yin, R. K. (2013). Case study research: Design and methods. Thousand Oaks: Sage Publications.

Yu, H. (2002). Web accessibility and the law: Recommendations for implementation. Library Hi Tech, 20, 406-419. https://doi.org/10.1108/07378830210452613

Zemer, L., \& Gaon, A. (2015). Copyright, disability and social inclusion: The Marrakesh Treaty and the role of nonsignatories. Journal of Intellectual Property Law \& Practice, 10, 836-849. https://doi.org/10.1093/jip/p/jpv149

\section{Correspondence to:}

G. Anthony Giannoumis

Oslo and Akershus University College of Applied Sciences

Postboks 4 St. Olavs plass

0130 Oslo

Email: gagian@hioa.no 


\section{About Authors}

Anthony Giannoumis' research focuses on technology law and policy. He is currently researching the implementation of policies aimed at ensuring equal access to technology. His research interests include universal design, international governance, social regulation, and standardization, and he has also conducted research on assistive technology, and intellectual property.

He is currently an assistant professor of universal design at the Department of Computer Science at Oslo and Akershus University College, and an international research fellow at the Burton Blatt Institute at Syracuse University.

Anthony has previously acted as a researcher with DISCIT - making persons with disabilities full citizens, and a legal and ethical advisor for Cloud4All - Cloud platforms lead to open and universal access for people with disabilities and for all. He was awarded aMarie Curie Fellowshipin 2011 as part of DREAM - Disability Rights Expanding Accessible Markets and has been a visiting researcher and guest lecturer throughout Europe, North America, Asia and Africa.

International law and human rights scholar Molly Land joined the UConn Law faculty in 2013. Drawing on her human rights expertise and background as an intellectual property litigator, Professor Land's scholarship focuses on the effect of new technologies on human rights fact-finding, advocacy, and enforcement, as well as the role of human rights norms and framing strategies in organizing around human rights issues. Her current work explores the extent to which human rights law can provide a foundation for claims of access to the Internet as well as the opportunities and challenges for using new technologies to achieve human rights objectives.

Professor Land's articles have been published in the Yale, Harvard, and Michigan journals of international law, among other places, and she speaks and lectures widely on the relationship between technology and human rights advocacy. She has also authored several human rights reports, including a report for the World Bank on the role of new technologies in promoting human rights. Prior to joining the UConn faculty, Professor Land was an associate professor of law at New York Law School, where she taught International Human Rights, Civil Procedure, International Intellectual Property, and other courses. Her teaching experience also includes serving as a visiting lecturer in law and Allard K. Lowenstein/Robert M. Cover Fellow in International Human Rights at Yale Law School. A former Fulbright Scholar at the University of Bonn, Professor Land earned her J.D. at Yale Law School.

Wondwossen Mulualem Beyene is a PhD Research Fellow working at the department of Computer Science, Universal Design of ICT research group. His research activity focuses on universal access of Information in the context of digital library environments. Beyene additional has an M.Sc in Health informatics and a Joint masters in Digital Library Learning (DILL).

Dr. Peter Blanck is University Professor at Syracuse University, which is the highest faculty rank granted to eight prior individuals in the history of the University. He is Chairman of the Burton Blatt Institute (BBI) at Syracuse University.

Blanck holds appointments at the Syracuse University Colleges of Law, and Arts and Sciences, David B. Falk College of Sport and Human Dynamics, School of Education, and the Maxwell School of Citizenship and Public Affairs. Prior to his appointment at Syracuse, Blanck was Kierscht Professor of Law and director of the Law, Health Policy, and Disability Center at the University of lowa. Blanck is Honorary Professor, Centre for Disability Law \& Policy, at the National University of Ireland, Galway. Blanck received a Bachelor of Arts from the University of Rochester, a Juris Doctorate from Stanford University, where he was President of the Stanford Law Review, and a Ph.D. in Social Psychology from Harvard University.

Editorial record: First submission received on January 6, 2017. Revision received on April 12, 2017. Accepted for publication on May 5, 2017. The article is part of Special Issue "Internet use and disability - Risks, opportunities and challenges" guest edited by Emma Sorbring and Martin Molin. 